\title{
THE ROLE OF GENERAL AND OCCUPATIONAL STRESS IN THE RELATIONSHIP BETWEEN WORKAHOLISM AND WORK-FAMILY/FAMILY-WORK CONFLICTS
}

\author{
MATEUSZ HAUK ${ }^{1}$ and JAN CHODKIEWICZ ${ }^{2}$ \\ ${ }^{1}$ Institute of Psychology, University of Łódź, Łódź, Poland \\ Department of Occupational and Counseling Psychology \\ ${ }^{2}$ Institute of Psychology, University of Lódź, Łódź, Poland \\ Department of Health Psychology
}

\begin{abstract}
Introduction: The purpose of this study was to analyze the role of general and occupational stress in the relationship between workaholism (recognized in two ways: as addiction and as behavioral tendency) and the intensity of work-family and familywork conflict. Materials and Methods: The study included 178 working people. The survey was conducted at three stages - half a year before a holiday, right after the holiday and half a year after the holiday. The Excessive Work Involvement Scale (SZAP) by Golińska for the measurement of workaholism recognized as addiction; The Scale of Workaholism as Behavioral Tendencies (SWBT) by Mudrack and Naughton as adapted by Dudek et al for the measurement of workaholism as behavioral tendency; the Perceived Stress Scale by Cohen et al., as adapted by Juczyński for the measurement of general stress; the Scale of Occupational Stress by Stanton in the adaptation of Dudek and Hauk for measurement of occupational stress; the Scale of Work-Family Conflict WFC/FWC by Netemeyer et al. with the Polish adaptation of A.M. Zalewska. Workaholism was measured once - before a holiday, the explained and intervening variables (the level of conflicts and stress, respectively) were measured at three stages. To test the mediating role of general and occupational stress, hierarchical regression analysis as well as the method of bootstrapping were applied. Results and Conclusions: Our results indicate that general stress is an important mediator of the relationship between workaholism recognized as an addiction and work-family conflicts. Occupational stress turned out to be the only mediator in the relationship between workaholism (recognized as an addiction) and the work-family conflict, noted exclusively in the first stage of the study. Both general and occupational stress were not significant mediators in the relationship between workaholism recognized as a behavioral tendency and the conflicts described.
\end{abstract}

Key words:

Workaholism, Work-family/family-work conflict, Effect of mediation, Bootstrapping

\section{INTRODUCTION}

According to many authors dealing with workaholism, its essence boils down to the fact that work is not only an essential condition for the wellbeing of individuals, but it begins to dominate over other forms of undertaken activities or significantly restricts them, winning the decisive place in thought processes [1-3]. Such a way of accounting for this phenomenon implies the possibility of the emergence of many forms of damage to the health of the worker and that of their close, as well as distant, social relationships, including the functioning of their family.

Research under the Ministerial Grant Number NN106332334: "Social, psychological and health consequences of workaholism". Project manager: Associate Professor Bohdan Dudek.

Received: June 4, 2012. Accepted: November 29, 2012.

Corresponding author: M. Hauk, Institute of Psychology, University of Łódź, Smugowa 10/12, 91-433 Łódź, Poland (e-mail: mateuszhauk@poczta.onet.pl). 
The negative effect of workaholism on family relationships is shown, inter alia, in the interviews with the wives of workaholics conducted by Robinson [1]. These women reported feeling ignored and underestimated, loneliness, abandonment in marriage and manipulation on the part of their husbands. They believed that they bore the whole burden of marriage and parenthood. All this resulted in enlarging the gap between the spouses. In other studies, it was found that in families where the husband was a workaholic, the wives often abandoned their own careers and achieving important objectives in the name of promoting the careers of their husbands [4]. It turned out that the wives of workaholics, in comparison to the wives of non-workaholics, considered their relationships more problematic and felt less positive feelings toward their husbands [5]. The studies of Garson [6] demonstrated that a higher intensity of workaholism positively correlates with the level of perceived family dysfunction measured by such indicators as worse communication, less effective problem solving and imprecisely defined roles.

The results cited above imply the possibility of conflicts between work and family life. Conflicts between the spheres of activity occur when the requirements related to the implementation of one of them negatively affect the functioning of the other [7]. It can also be specified as a conflict of roles which cannot be reconciled with equal commitment [8].

Greenhaus and Beutell [9] distinguish two types of conflict: work-family, which takes place when the job demands make it difficult to participate in family life, and family-work, which occurs when family responsibilities make it difficult to function as a professional. The main components of these conflicts are the requirements posed by the two roles (e.g. responsibilities, commitment), the time devoted to them (e.g. when the activity in one of the roles takes time, which should be devoted to the other), and tension associated with these activities (when the tension caused by the activity in one of the roles affects the functioning in the other, as noted by Bachrach et al. [10]).
Numerous studies have shown that such conflicts accompany decreased satisfaction with both work and marriage, weaker perceived and procured social support, professional burnout, a greater amount of absenteeism at work and high level of stress, mental and physical ailments, and alcohol abuse [7,9,11-21]. A meta-analysis of 60 studies on workfamily and family-work conflict performed by Byron [18] also shows that these conflicts are related to the intensity of family and occupational stress. It should be noted that, although the highlighted conflicts are related, it does not necessarily mean that both have the same consequences [7,18,20]. In longitudinal studies, rarely carried out in relation to this matter, Frone et al. [22] have shown that work-family conflict is significantly associated with heavy drinking, and family-work conflict has a relationship with elevated levels of depression and deterioration of physical health (e.g. hypertension).

The above overview shows numerous, well-documented relationships between workaholism and changes in family functioning (including work-family conflicts). However, it should be noted that a paucity of research exists in the literature which would describe (in a direct way) the relationship between workaholism and the level of workfamily/family-work conflict. It is worth mentioning that it was proved that workaholism (understood as an addiction) showed a positive relationship with both types of conflicts at each stage (half a year before a holiday, during a holiday, right after a holiday) [23].

On the other hand, a number of reports exist showing the positive relationship of workaholism with general and occupational stress [24-29]. In previous studies, attempts to determine about the relationship of these variables were not made.

The situation is further complicated by discrepancies in the understanding of workaholism and the variety of tools used for the measurement of this phenomenon. The role of measurement tools can be very important in the process of diagnosing the consequences of workaholism (they can differ relating to the tool being used) [23]. As for the variations in 
the understanding of workaholism, Griffiths [30] considers workaholism as an addiction with a characteristic for each of the addiction symptoms (increased tolerance, withdrawal symptoms, relapse, mood regulation through work). Robinson [31] describes the phenomenon of workaholism as a compulsive need to work and exaggerated permission to do so which can decrease (as a consequence) the functioning in other life activities. Wojdyło [32] draws attention to the obsessive-compulsive nature of this disorder, and Mudrack and Naughton [33] understand workaholism as a tendency towards unnecessary activity that is not expected by an employer and an intrusive striving for control over co-workers. This can be described as the so-called behavioral approach to workaholism.

In this study, we attempt to answer questions about the role of general and occupational stress in the relationship between workaholism and family functioning. It was decided to use two tools to measure workaholism - an approach based on workaholism as an addiction (SZAP) and a tool showing it as a behavioral tendency (SWBT). The specific objectives were to answer the research questions:

- can general stress be regarded as a mechanism by which workaholism affects the intensity of the analyzed conflicts,

- can occupational stress be regarded as a mechanism by which workaholism affects the intensity of the analyzed conflicts,

- does the tool used to measure workaholism differentiate the results?

In this paper, due to the lack of similar studies in the literature, it was decided not to state research hypotheses.

\section{MATERIALS AND METHODS}

\section{The study procedure and the study group}

Most research on workaholism is conducted according to the cross-section procedure of measuring the phenomenon with a single method. As a consequence, the obtained results do not allow conclusions to be drawn about the causal nature of the relationship. Furthermore, the assessment of the quality of the method being used is not possible. In our study, we conducted a procedure which makes it possible to avoid these negative consequences. The study was of longitudinal character measuring conflicts and stress levels at three stages, half a year before a holiday, right after the holiday and half a year later. The main objective was to examine how the level of WFC/ FCW will change in relation to going on holidays depending on the level of workaholism. It was assumed that the state of being at work, waiting for the holiday and being after the holiday were the states that may affect the person being tested and the conditions of his/her family functioning. Workaholism was measured only once - in the first stage.

The study involved 178 people aged 23-66 years, 71 men and 107 women, working for a minimum of 4 years. The mean age was 43.40 ( $\mathrm{SD}=8.42), 75.5 \%$ of the subjects had completed higher education, and the remaining ones had incomplete higher and secondary education. A total of $128(71.91 \%)$ of the respondents occupied managerial positions at the time of the study. The occupations represented most frequently in the study sample included manager, banker, official and administrative staff, doctor, teacher and lawyer.

\section{The applied measurement tools}

The tools applied were as follows:

1. To measure workaholism:

- Scale of Workaholism as Behavioral Tendencies (SWBT) by Mudrack and Naughton with Polish adaptation by Dudek, Hauk and Merecz [34]. This is a 12-item questionnaire consisting of two subscales titled: 1) nonrequired work (6 items, e.g. "Thinking about ways to become more efficient") and 2) control of others (6 items, e.g. "Exerting pressure on others to do their work faster and better"). The psychometric properties of the tool seem to be satisfactory: Cronbach's $\alpha$ for the whole 
tool $=0.87$; for the non-required excessive occupational activity $=0.80$; for the control of others $=0.85$; test retest stability for the whole tool $=0.92$; for the nonrequired excessive occupational activity $=0.90$; for the control of others $=0.80$.

- Excessive Work Involvement Scale (SZAP) by Golińska [29]. This is a 27-item questionnaire consisting of four subscales titled: 1) being absorbed by work (12 items, e.g. "Sometimes I think that my commitment to work has a bad influence on my relationships with my family"); 2) compulsion to work (4 items, e.g. "It often occurs to me that the holiday which does not give the possibility to deal with work is too long for me"); 3 ) work as a regulator of emotions (6 items, e.g. "When I'm in a bad mood, the most effective remedy is to completely dedicate myself to work"); 4) belief system that protects the addiction (3 items, e.g. "I believe that work makes a man more valuable"). Cronbach's $\alpha$ values were as follows: subscale $1=0.90$, subscale $2=0.70$, subscale $3=0.44$, subscale $4=0.53$. The test-retest stability for the whole tool equaled 0.60 .

2. The Scale of Work-Family Conflict WFC/FWC by Netemeyer, Boles and McMurrian with the Polish adaptation by A.M. Zalewska [7]. This is a 10 -item questionnaire The tool consists of two scales. The first is used to measure work-family conflict (WFC), while the second - family-work conflict (FWC). The method has good psychometric properties. Cronbach's $\alpha$ for the work-family conflict scale (WFC) $=0.94$; for the family-work conflict scale $(\mathrm{FWC})=0.80$ [7].

3. The Perceived Stress Scale (PSS) with the Polish adaptation by Juczyński. This is a 10-item questionnaire. The scale is used to assess the stress connected with one's life situation over the last month. The higher the score, the greater the severity of the stress. The method is characterized by good psychometric properties [35]. Cronbach's $\alpha=0.81$.
4. The scale of occupational stress by Stanton as adapted by B. Dudek and M. Hauk. This is a 26-item questionnaire. The tool is used to assess the level of occupational stress, it consists of five subscales: pressure, attractiveness, liking, risk, peace of mind. It is also possible to make a diagnosis of a global sense of occupational stress. The higher the score, the greater the severity of the stress. The method is characterized by good psychometric properties [36]. Cronbach's $\alpha$ for the whole tool $=0.86$.

Analyses were carried out in the following order:

- First, a hierarchical regression analysis was conducted [37], the first step was to introduce solely workaholism as a predictor (respectively SZAP, SWBT), while the second was to add another variable (general stress and occupational stress, respectively). Figure 1 presents a general model of the relationship. Path c shows a direct correlation between workaholism and work-family/ family-work conflict (WFC/FWC), while path c' shows the indirect effect of workaholism on WFC/FWC (with the control of the mediator being stress). Other paths

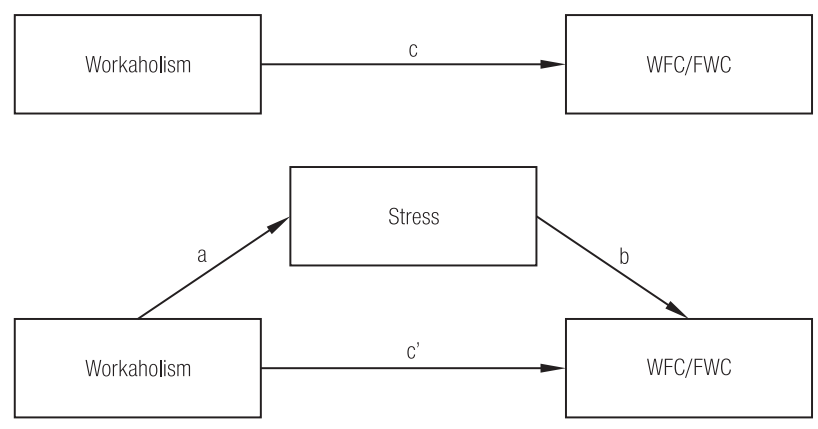

a - presents the relationship between workaholism and the mediator (stress).

$\mathrm{b}$ - presents the relationship between the mediator (stress) and the work-family conflicts/family-work conflicts (WFC/FWC). $\mathrm{c}$ - presents a direct correlation between workaholism and work-family conflicts/family-work conflicts (WFC/FWC).

c' - presents the indirect effect of workaholism on WFC/FWC (with the control of the mediator being stress).

Fig. 1. Model of the relationships between workaholism, stress and work-family/family-work conflicts (WFC, FWC) 
refer to the relationship between workaholism and the mediator (path a) and between the mediator and WFC/ FWC (path b).

- Second, the INDIRECT macro described by Preacher and Hayes [38] was used. Workaholism was introduced as an explanatory variable, stress as a mediator, and work-family/family-work conflict as a variable to be explained. It should be noted that the measurement of workaholism was made once - before a holiday, while measuring the explained and intervening variables (the level of conflicts and stress, respectively) at three time points. Due to the relatively small sample size, analysis was performed using the method of bootstrapping (it was chosen to bootstrap 5000 samples). Bootstrapping is now commonly used to analyze the effects of mediation. It can be characterized as a procedure of generating a sample of a distribution, treating it as a miniature representation of the whole population. It is worth noting that the test involved multiple drawing with replacement from the sample. Simulation analyses indicate that this method has greater power than other commonly used tests, such as the Sobel Test [37].

\section{RESULTS}

The results for SZAP and SWBT were shown separately. It was also decided to describe the relationship in detail at every stage of the research, introducing one intervening variable.

As first, an analysis of the role of general stress in the relationship between workaholism (measured with SZAP) and work-family/family-work conflict (WFC/FWC) at different stages of research was performed. The results are presented below in Table 1.

Table 1. The mediating role of general stress in the relationship between workaholism measured with SZAP and work-family/familywork conflicts at various stages of the research

\begin{tabular}{|c|c|c|c|c|c|c|c|}
\hline \multirow[b]{2}{*}{$\begin{array}{l}\text { Conflict } \\
\text { type }\end{array}$} & \multirow[b]{2}{*}{$\begin{array}{l}\text { Research } \\
\text { stage }\end{array}$} & \multicolumn{4}{|c|}{ Hierarchical regression (â value) } & \multirow[b]{2}{*}{$\begin{array}{l}\text { Total indirect } \\
\text { effect (range) }\end{array}$} & \multirow[b]{2}{*}{$\begin{array}{c}\text { Mediation } \\
\text { effect }\end{array}$} \\
\hline & & $\begin{array}{l}\text { direct correlation: } \\
\text { predictor - response } \\
\text { variable (âc) }\end{array}$ & $\begin{array}{c}\text { correlation: } \\
\text { explanatory } \\
\text { variable - mediator } \\
\text { (âa) }\end{array}$ & $\begin{array}{l}\text { correlation: } \\
\text { mediator - response } \\
\text { variable (âb) }\end{array}$ & $\begin{array}{l}\text { indirect correlation: } \\
\text { predictor - } \\
\text { response variable, } \\
\text { with mediator } \\
\text { control (âc') }\end{array}$ & & \\
\hline WFC & 1 & $\begin{array}{c}0.461 \\
p<0.001\end{array}$ & $\begin{array}{c}0.265 \\
p<0.001\end{array}$ & $\begin{array}{c}0.277 \\
p<0.001\end{array}$ & $\begin{array}{c}0.417 \\
p<0.001\end{array}$ & $0.0079-0.0668$ & yes \\
\hline FWC & & $\begin{array}{c}0.231 \\
p<0.01\end{array}$ & $\begin{array}{c}0.265 \\
p<0.001\end{array}$ & $\begin{array}{c}0.217 \\
p<0.01\end{array}$ & $\begin{array}{c}0.188 \\
p<0.05\end{array}$ & $0.0055-0.0500$ & yes \\
\hline WFC & 2 & $\begin{array}{c}0.376 \\
p<0.001\end{array}$ & $\begin{array}{c}0.173 \\
p<0.05\end{array}$ & $\begin{array}{c}0.288 \\
p<0.001\end{array}$ & $\begin{array}{c}0.339 \\
p<0.001\end{array}$ & $0.0070-0.0687$ & yes \\
\hline FWC & & $\begin{array}{c}0.199 \\
p<0.01\end{array}$ & $\begin{array}{c}0.173 \\
p<0.05\end{array}$ & $\begin{array}{c}0.357 \\
p<0.001\end{array}$ & $\begin{array}{c}0.143 \\
p<0.05\end{array}$ & $0.0081-0.0697$ & yes \\
\hline WFC & 3 & $\begin{array}{c}0.376 \\
p<0.001\end{array}$ & $\begin{array}{c}0.206 \\
p<0.01\end{array}$ & $\begin{array}{c}0.226 \\
p<0.01\end{array}$ & $\begin{array}{c}0.343 \\
\mathrm{p}<0001\end{array}$ & $0.0016-0,0565$ & yes \\
\hline FWC & & $\begin{array}{c}0.100 \\
p=0.172\end{array}$ & $\begin{array}{c}0.206 \\
p<0.01\end{array}$ & $\begin{array}{c}0.242 \\
p<0.001\end{array}$ & $\begin{array}{c}0.052 \\
\mathrm{p}=0.476\end{array}$ & $0.0059-0.0492$ & yes \\
\hline
\end{tabular}

WFC - work-family conflict; FWC - family-work conflict.

Other abbreviations as in Figure 1. 
As shown in the Table above, at each stage of the research, the conditions for the recognition of general stress as an important mediator of the relationship between workaholism (SZAP) and work-family conflict, and the relationship between workaholism (SZAP) and family-work conflict are met. The results of the hierarchical regression analysis in each case show that the variable introduced into the equation - general stress - weakens the relationship between the predictor and the response variable, which should be interpreted as an instance of the effect of mediation. The results (using the bootstrapping method) showed that the total indirect effect is in the range not containing the value 0 (95\% bias corrected); this is significant, which confirms the mediating role of general stress in the above relationship at every stage of research.

A similar operation was carried out for the second measure of workaholism - SWBT. The results are shown below.
As displayed in Table 2, many correlations state that no significant relationship exists between workaholism (measured with SWBT) and conflicts, as well as workaholism and general stress. One could say that the bootstrapping method is unnecessary. On the other hand, it should be emphasized that the bootstrapping method does not require a correlation between the explanatory and the explained variable. Thus, we decided to conduct all analyses and define the status of the general stress in each case.

As manifested by both analyzed correlations, it is impossible, at any stage, to prove that general stress is a mediator of the relationship between workaholism (measured with SWBT) and conflicts. It is worth noting that only at the first stage of the study (before a holiday) the results of hierarchical regression analysis indicate that the variable - general stress - entered into the equation weakens the relationship between the predictor and the dependent

Table 2. The mediating role of general stress in the relationship between workaholism measured with SWBT and work-family/familywork conflicts at various stages of the research

\begin{tabular}{|c|c|c|c|c|c|c|c|}
\hline \multirow[b]{2}{*}{$\begin{array}{l}\text { Conflict } \\
\text { type }\end{array}$} & \multirow[b]{2}{*}{$\begin{array}{l}\text { Research } \\
\text { stage }\end{array}$} & \multicolumn{4}{|c|}{ Hierarchical regression (â value) } & \multirow[b]{2}{*}{$\begin{array}{l}\text { Total indirect } \\
\text { effect (range) }\end{array}$} & \multirow[b]{2}{*}{$\begin{array}{c}\text { Mediation } \\
\text { effect }\end{array}$} \\
\hline & & $\begin{array}{l}\text { direct correlation: } \\
\text { predictor - response } \\
\text { variable (âc) }\end{array}$ & $\begin{array}{c}\text { correlation: } \\
\text { explanatory } \\
\text { variable - mediator } \\
\text { (âa) }\end{array}$ & $\begin{array}{l}\text { correlation: } \\
\text { mediator - response } \\
\text { variable (âb) }\end{array}$ & $\begin{array}{l}\text { indirect correlation: } \\
\text { predictor - } \\
\text { e response variable, } \\
\text { with mediator } \\
\text { control (âc') }\end{array}$ & & \\
\hline WFC & 1 & $\begin{array}{c}0.136 \\
p=0.066\end{array}$ & $\begin{array}{c}0.001 \\
p=0.989\end{array}$ & $\begin{array}{c}0.277 \\
p<0.001\end{array}$ & $\begin{array}{c}0.129 \\
\mathrm{p}=0.070\end{array}$ & $-0.0311-0.0442$ & no \\
\hline FWC & & $\begin{array}{c}0.165 \\
p<0.05\end{array}$ & $\begin{array}{c}0.001 \\
p=0.989\end{array}$ & $\begin{array}{c}0.217 \\
p<0.01\end{array}$ & $\begin{array}{c}0.160 \\
p<0.05\end{array}$ & $-0.0192-0.0285$ & no \\
\hline WFC & 2 & $\begin{array}{c}0.201 \\
p<0.01\end{array}$ & $\begin{array}{c}-0.058 \\
p=0.429\end{array}$ & $\begin{array}{c}0.288 \\
p<0.001\end{array}$ & $\begin{array}{c}0.219 \\
p<0.01\end{array}$ & $-0.0649-0.0269$ & no \\
\hline FWC & & $\begin{array}{c}0.014 \\
p=0.848\end{array}$ & $\begin{array}{c}-0.058 \\
p=0.429\end{array}$ & $\begin{array}{c}0.357 \\
p<0.001\end{array}$ & $\begin{array}{c}0.035 \\
p=0.611\end{array}$ & $-0.0612-0.0221$ & no \\
\hline WFC & 3 & $\begin{array}{c}0.124 \\
p=0.091\end{array}$ & $\begin{array}{c}-0.088 \\
\mathrm{p}=0.232\end{array}$ & $\begin{array}{c}0.226 \\
p<0.01\end{array}$ & $\begin{array}{c}0.147 \\
p<0.05\end{array}$ & $-0.0610-0.0142$ & no \\
\hline FWC & & $\begin{array}{c}-0.024 \\
p=0.746\end{array}$ & $\begin{array}{c}-0.088 \\
p=0.232\end{array}$ & $\begin{array}{c}0.242 \\
p<0.001\end{array}$ & $\begin{array}{c}-0.002 \\
p=0.977\end{array}$ & $-0.0432-0.0094$ & no \\
\hline
\end{tabular}

Abbreviations as in Table 1. 
Table 3. The mediating role of occupational stress in relation to workaholism measured with SZAP and the work-family/familywork conflicts at various stages of the research

\begin{tabular}{|c|c|c|c|c|c|c|c|}
\hline \multirow[b]{2}{*}{$\begin{array}{l}\text { Conflict } \\
\text { type }\end{array}$} & \multirow[b]{2}{*}{$\begin{array}{l}\text { Research } \\
\text { stage }\end{array}$} & \multicolumn{4}{|c|}{ Hierarchical regression (â value) } & \multirow[b]{2}{*}{$\begin{array}{l}\text { Total indirect } \\
\text { effect (range) }\end{array}$} & \multirow[b]{2}{*}{$\begin{array}{c}\text { Mediation } \\
\text { effect }\end{array}$} \\
\hline & & $\begin{array}{l}\text { direct correlation: } \\
\text { predictor - response } \\
\text { variable (âc) }\end{array}$ & $\begin{array}{c}\text { correlation: } \\
\text { explanatory } \\
\text { variable - mediator } \\
\quad \text { (âa) }\end{array}$ & $\begin{array}{l}\text { correlation: } \\
\text { mediator - response } \\
\text { variable (âb) }\end{array}$ & $\begin{array}{l}\text { indirect correlation: } \\
\text { predictor - } \\
\text { response variable, } \\
\text { with mediator } \\
\text { control (âc') }\end{array}$ & & \\
\hline WFC & 1 & $\begin{array}{c}0.478 \\
\mathrm{p}<0.001\end{array}$ & $\begin{array}{c}0.151 \\
p<0.05\end{array}$ & $\begin{array}{c}0.293 \\
\mathrm{p}<0.001\end{array}$ & $\begin{array}{c}0.444 \\
\mathrm{p}<0.001\end{array}$ & $0.0030-0.0539$ & yes \\
\hline FWC & & $\begin{array}{c}0.211 \\
p<0.01\end{array}$ & $\begin{array}{c}0.151 \\
p<0.05\end{array}$ & $\begin{array}{c}0.032 \\
p=0.664\end{array}$ & $\begin{array}{c}0.211 \\
p<001\end{array}$ & $-0.0136-0.0130$ & no \\
\hline WFC & 2 & $\begin{array}{c}0.376 \\
p<0.001\end{array}$ & $\begin{array}{c}0.092 \\
p=0.216\end{array}$ & $\begin{array}{c}0.244 \\
p<0.001\end{array}$ & $\begin{array}{c}0.357 \\
p<0.001\end{array}$ & $-0.0047-0.0504$ & no \\
\hline FWC & & $\begin{array}{c}0.201 \\
p<0.01\end{array}$ & $\begin{array}{c}0.092 \\
p=0.216\end{array}$ & $\begin{array}{c}0.144 \\
\mathrm{p}=0.052\end{array}$ & $\begin{array}{c}0.191 \\
p<0.01\end{array}$ & $-0.0015-0.0218$ & no \\
\hline WFC & 3 & $\begin{array}{c}0.364 \\
p<0.001\end{array}$ & $\begin{array}{c}0.025 \\
p=0.729\end{array}$ & $\begin{array}{c}0.208 \\
p<0.01\end{array}$ & $\begin{array}{c}0.359 \\
p<0.001\end{array}$ & $-0.0147-0.0245$ & no \\
\hline FWC & & $\begin{array}{c}0.080 \\
p=0.276\end{array}$ & $\begin{array}{c}0.025 \\
p=0.729\end{array}$ & $\begin{array}{c}0.090 \\
p=0.217\end{array}$ & $\begin{array}{c}0.078 \\
p=0.290\end{array}$ & $-0.0048-0.0117$ & no \\
\hline
\end{tabular}

Abbreviations as in Table 1.

variable (for both WFC and FWC). Further analysis in turn (using the bootstrapping method) showed that the total indirect effect is in the range containing the value 0 ( $95 \%$ bias corrected), it is negligible, which does not confirm the mediating role of general stress.

At the remaining stages, the introduction of the mediator to the regression equation results in a slight increase in the relationship between the predictor and the response variable (which excludes the effect of mediation, pointing rather to the effect of suppression). Nevertheless further analysis did not confirm any of the indirect effects [37]. In the later phase of the analysis, the role of occupational stress in relation to workaholism (measured with SZAP) and the work-family/family-work conflict (WFC/FWC) was examined. The analysis was identical to those described above. The results are shown in Table 3.

Although some results reveal relationships between workaholism, conflicts and occupational stress that are not significant, it was decided to conduct all analyses and define the mediating effect in each case.

As it is shown in the table above, occupational stress is a mediator only in the relationship between workaholism (measured with SZAP) and the work-family conflict at the first stage of the study. In other cases, the hierarchical regression analysis as well as the method of bootstrapping do not confirm the effect of mediation.

The same operation was carried out for the second measure of workaholism - SWBT. Similarly to the procedure listed above, all analyses aimed at defining the status of occupational stress were conducted. The results are presented in Table 4.

As it can be seen in the above table, it cannot be shown that occupational stress is a mediator of the relationship between workaholism (as measured with SWBT) and the analyzed conflicts at any stage of the studies. 
Table 4. The mediating role of occupational stress in relation to workaholism measured with SWBT and work-family/family-work conflicts at various stages of research

\begin{tabular}{|c|c|c|c|c|c|c|c|}
\hline \multirow[b]{2}{*}{$\begin{array}{l}\text { Conflict } \\
\text { type }\end{array}$} & \multirow[b]{2}{*}{$\begin{array}{l}\text { Research } \\
\text { stage }\end{array}$} & \multicolumn{4}{|c|}{ Hierarchical regression (â value) } & \multirow[b]{2}{*}{$\begin{array}{l}\text { Total indirect } \\
\text { effect (range) }\end{array}$} & \multirow[b]{2}{*}{$\begin{array}{c}\text { Mediation } \\
\text { effect }\end{array}$} \\
\hline & & $\begin{array}{l}\text { direct correlation: } \\
\text { predictor - response } \\
\text { variable (âc) }\end{array}$ & $\begin{array}{c}\text { correlation: } \\
\text { explanatory } \\
\text { variable - mediator } \\
\text { (âa) }\end{array}$ & $\begin{array}{l}\text { correlation: } \\
\text { mediator - response } \\
\text { variable (âb) }\end{array}$ & $\begin{array}{l}\text { indirect correlation: } \\
\text { predictor - } \\
\text { e response variable, } \\
\text { with mediator } \\
\text { control (âc') }\end{array}$ & & \\
\hline WFC & 1 & $\begin{array}{c}0.120 \\
p=0.105\end{array}$ & $\begin{array}{c}0.003 \\
p=0.963\end{array}$ & $\begin{array}{c}0.293 \\
p<0.001\end{array}$ & $\begin{array}{c}0.119 \\
\mathrm{p}=0.095\end{array}$ & $-0.0299-0.0376$ & no \\
\hline FWC & & $\begin{array}{c}0.155 \\
p<0.05\end{array}$ & $\begin{array}{c}0.003 \\
p=0.963\end{array}$ & $\begin{array}{c}0.032 \\
p=0.664\end{array}$ & $\begin{array}{c}0.155 \\
p<0.05\end{array}$ & $-0.0056-0.0094$ & no \\
\hline WFC & 2 & $\begin{array}{c}0.190 \\
p<0.01\end{array}$ & $\begin{array}{c}0.018 \\
p=0.811\end{array}$ & $\begin{array}{c}0.244 \\
p<0.001\end{array}$ & $\begin{array}{c}0.186 \\
p<0.01\end{array}$ & $-0.0260-0.04199$ & no \\
\hline FWC & & $\begin{array}{c}0.005 \\
\mathrm{p}=0.948\end{array}$ & $\begin{array}{c}0.018 \\
p=0.811\end{array}$ & $\begin{array}{c}0.144 \\
p=0.052\end{array}$ & $\begin{array}{c}0.002 \\
p=0.975\end{array}$ & $-0.0119-0.0192$ & no \\
\hline WFC & 3 & $\begin{array}{c}0.092 \\
p=0.216\end{array}$ & $\begin{array}{c}-0.062 \\
\mathrm{p}=0.404\end{array}$ & $\begin{array}{c}0.208 \\
p<0.01\end{array}$ & $\begin{array}{c}0.106 \\
p=0.146\end{array}$ & $-0.0493-0.0151$ & no \\
\hline FWC & & $\begin{array}{c}-0.047 \\
p=0.528\end{array}$ & $\begin{array}{c}-0.062 \\
p=0.404\end{array}$ & $\begin{array}{c}0.090 \\
p=0.217\end{array}$ & $\begin{array}{c}-0.041 \\
\mathrm{p}=0.583\end{array}$ & $-0.0235-0.0034$ & no \\
\hline
\end{tabular}

Abbreviations as in Table 1.

\section{DISCUSSION}

First, it is worth making a general conclusion concerning the links between workaholism, stress and WFC/FWC. Some of the results provided above show that no significant relationship exists between these variables. An earlier analysis [23] showed differences in the relationship between workaholism and the two conflicts (e.g. in the case of family-work conflict, the relationship was not always present). The obtained results suggest the need for examining more variables in the model tested, it is also worth considering whether a so-called suppression effect exists in this relationship, and whether the inclusion of other intermediate variables would increase the predictive properties of the independent variable [37]. It would seem appropriate to continue studying the relationship between workaholism by including a range of possible mediating factors. Such a need is also suggested by a meta-analysis of these conflicts conducted by Byron [18] and Michel et al. [39], indicating their distinct conditions; work-related stressors, the level of neuroticism and locus of control showed a relationship with work-family conflict, while the stressors associated with family such as the lack of clarity of roles and the level of social support were associated with familywork conflict.

The obtained results give partial answers to the research questions. Stress is an important mediator of the overall relationship between workaholism (measured with SZAP) and work-family life conflicts at every stage of the research. However, in the case of workaholism recognized as behavioral tendency (SWBT), it cannot be shown that stress is a mediator of the relationship workaholism-conflicts at any stage of the research.

In conclusion, it must be said that in the case of the research questions concerning the role of general stress as a mediator in the workaholism-conflicts relationship, the answer obtained is only a partial confirmation of the assumed relationship. The postulated relationship was 
demonstrated only for the relationship between workaholism recognized as an addiction and work-family life conflicts (WFC/FWC).

The above results lead at the same time to the answer to the third research question, namely the kind of the tool used to measure workaholism is important for the outcomes of the study and significantly differentiates the results. The two methods used to measure workaholism (SZAP and SWBT) do not show similar correlations. The results also provide a contribution to the discussion on the symptoms, the presence of which is necessary in order to diagnose the syndrome of workaholism and describe its effects.

Regarding the second question concerning the mediating role of occupational stress in the relationship of workaholism and professional life-private life conflicts, the results are not so clear. Occupational stress is a mediator only in relation to workaholism (measured with SZAP) and the work-family conflicts in the first stage of research, i.e. six months before the holiday. It can be said that people "addicted" to work indulging in professional life, being before the rest, experience severe occupational stress, which increases the level of conflicts between their work and home activity. This dependence disappears in the next stages of the research (i.e. during the holiday and 6 months after the holiday). It can be assumed that relaxation in the case of people "addicted" to work results in decreasing the stress and tension connected with work, which reduces the severity of the conflicts. Further research is needed concerning this relationship and the role of occupational stress in the context of perceived conflicts connected with the professional role of people with different levels of workaholism.

It is worth noting that occupational stress is not an important mediator in the relationship of workaholism (recognized as an addiction) and family-work conflicts (FWC). This result seems to be logical according to everyday reasoning, i.e. stress connected with the performed work affects conflicts arising from one's professional role more in private life, rather than vice versa. In this case, the level of conflicts resulting from one's family roles, general stress brings stronger interaction (as evidenced by the results). In the case of the second scale applied to measure workaholism (SWBT), occupational stress did not prove to be an important mediator of the relationship between workaholism and work-family/family-work conflicts at any stage of the research. Thus, earlier results concerning the differences in the application of the two methods for the diagnosis of workaholism were confirmed. One possible interpretation of these differences may be the fact that the scale for the Study of Work-Family and Family-Work Conflicts measures the cognitive assessment of these relationships, and SWBT focuses, as the authors assumed, on behavioral aspects - nonrequired work and control of others. Therefore, it seems advisable to use other methods of examining work-family conflicts in subsequent research using SWBT. At the same time it is recommended to do further research using SWBT, aimed at a more detailed description at the correlatives and consequences of workaholism measured as a behavioral tendency. Other studies [23] lead to similar conclusions, suggesting the need to re-verify the tool, mainly to check the dependencies that exist between the results obtained in the subscale "Control of others", which shows a stronger relationship with the work-family conflicts than the other subscale - "Non-required work" and the entire SWBT tool.

In conclusion, it should be noted that general stress is an important mediator of the relationship of workaholism, recognized as an addiction, and work-family conflicts. This is an important premise, which should encourage researchers to include this variable in the studies of workaholism as well. Occupational stress was a mediator only in the relationship between workaholism (recognized as an addiction) and work-family conflicts in the first stage of the study. This leads to the conclusion that occupational stress may have the greatest effect on the difficulties in family life arising from one's professional role. There is no significant impact on the family-work conflicts. 
Simultaneously, further results suggest that resting in the form of a holiday reduces the impact of that variable. This is an important prerequisite for practitioners dealing with human functioning at work. If there are persons "addicted" to work present within the organization, it seems important to plan the periods of rest and to encourage their use, which can reduce tension and consequently alleviate work-family conflicts.

Neither general stress nor occupational stress were significant mediators in the relationship between workaholism (recognized as a behavioral tendency) and the conflicts described above. This is an important conclusion which on the one hand, points to the need for further verification of the study tools (SWBT), and on the other hand, should prompt researchers and practitioners to carefully choose their diagnostic tools since these tools do not lead to identical or similar results.

\section{REFERENCES}

1. Robinson B. Work, stress and marriage: A theoretical model examine the relationship between workaholism and marital cohesion. Int J Stress Manage 2001;8:165-75.

2. Paluchowski WJ, Hornowska E. Workaholism, value system and temperamental conditions. In: Witkowski S, editor. Psychological determinants of success in management. Wrocław: Wydawnictwo Uniwersytetu Wrocławskiego; 2003. p. 297-321 [in Polish].

3. Golińska L. Workaholism - addiction or a passion. Warszawa: Difin; 2008 [in Polish].

4. Vodanovich SJ, Piotrowski C. Workaholism: A critical but neglected factor in O.D. Organ Dev J 2006;24(2):55-60.

5. Robinson B, Carroll JJ, Flowers C. Marital estrangement, positive affect and locus of control among spouses of workaholics and spouses of nonworkaholics: A national study. Am J Fam Ther 2001;29:397-410.

6. Garson B. Work addiction: Organizational boon or doom. Atlanta: Garson and Associates; 1990.
7. Zalewska AM. Work-family conflicts - their causes and consequences. Measurement of conflicts. In: Golińska L, Dudek B, editors. Family and work from the perspective of the challenges and threats. Łódź: Wydawnictwo Uniwersytetu Łódzkiego; 2008. p. 402-18 [in Polish].

8. Bakker AB, Demerouti E, Burke R. Workaholism and relationship quality: A spillover-crossover perspective. J Occup Health Psychol 2009;14:23-33.

9. Greenhaus J, Beutell N. Sources of conflict between work and family roles. Acad Manage Rev 1985;10:76-88.

10. Bachrach S, Bamberger P, Conley S. Work-home conflict among nurses and engineers: Mediating the impact of role stress on burnout and satisfaction at work. J Organ Behav 1991;12(1):39-53.

11. Burke RJ. Some antecedents and consequences of work-family conflict. J Soc Behav Pers 1988;3:287-302.

12. Adams GA, King LA, King DW. Relationships of Job and Family Involvement, Family Social Support, and Work-Family Conflict With Job and Life Satisfaction. J Appl Psychol 1996;81(4):411-20.

13. Greenhaus J, Collins KM, Singh R, Parasuraman S. Work and family influences on departure from public accounting. J Vocat Behav 1997;50:249-70.

14. Carlsson D, Kacmar K. Work-family conflict in the organization: do life role values make a difference. J Manage 2000;26:1031-54.

15. Frone MR. Work Stress and Alcohol Use. Alcohol Res Health 1999;23(4):284-91.

16. Frone MR. Work-family conflict and employee psychiatric disorders: The National Comorbidity Survey. J Appl Psychol 2000;85(6):888-95.

17. Greenglass E. Differences arising from gender roles, social support and coping with stress. In: Sęk H, Cieślak R, editors. Social support, stress and health. Warszawa: Wydawnictwo Naukowe PWN; 2004. p. 138-52 [in Polish].

18. Byron K. A meta-analytic review of work-family conflict and its antecedents. J Vocat Behav 2005;67:169-98.

19. Wang J, Afifi TO, Cox B, Sareen J. Work-family conflict and mental disorders in the United States: cross-sectional 
findings from The National Comorbidity Survey. Am J Ind Med 2007;50(2):143-9.

20. Lu L, Kao S, Chang T, Wu H, Cooper C. Work/family demands, work flexibility, work/family conflict, and their consequences at work: A national probability sample in Taiwan. Int Perspect Psychol Res Pract Consult 2011;1:68-81.

21. Janicka I. Work-family conflicts and the quality of life of the individual. In: Golińska L, Dudek B, editors. Family and work from the perspective of the challenges and threats. Lódź: Wydawnictwo Uniwersytetu Łódzkiego; 2008. p. 419-30 [in Polish].

22. Frone MR, Russel M, Cooper ML. Relation of work-family conflict to health outcomes: A four-year longitudinal study of employed parents. J Occup Organ Psychol 1997;70(4):325-36.

23. Chodkiewicz J, Hauk M. The relationship between workaholism defined as an addiction and a behavioral tendency and work-family conflict. Med Pr 2012;63(2):199-209 [in Polish].

24. Spence JT, Robbins AS. Workaholism: definition, measurement and preliminary results. J Pers Assess 1992;58(1): $160-78$.

25. McMillan LH, O’Driscoll MP, Marsh NV, Brady EC. Understanding workaholism: Data synthesis, theoretical critique, and future design strategies. Int J Stress Manage 2001;8:69-91.

26. Taris TW, Schaufeli WB, Verhoeven LC. Workaholism in the Netherlands: Measurement and implications for job strain and work-non-work conflict. Appl Psychol Int Rev 2005;54:37-60.

27. Burke RJ. Workaholism in organizations: Psychological and physical well-being consequences. Stress Med 2000;16:11-6.

28. Porter G. Organizational impact of workaholism: Suggestions for researching the negative outcomes of excessive work. J Occup Health Psychol 1996;1:70-84.

29. Dudek B, Szymczak W. Psychological, social and health consequences of workaholism. In: Dudek B, editor. Social, psychological and health consequences of workaholism. Łódź: Wydawnictwo Uniwersytetu Łódzkiego; 2011. p. 5-37 [in Polish].

30. Griffiths M. Workaholism is still a useful construct. Addict Res Theory 2005;13(2):97-100.

31. Robinson B.E. The workaholic family: A clinical perspective. Am J Fam Ther 1998;26:65-75.

32. Wojdyło K. The concept of personality determinants of workaholism. Verification of the assumptions by the correlation model. Stud Psychol 2007;45(3):53-65. [in Polish].

33. Mudrack PE, Naughton T. The Assessment of workaholism as behavioral tendencies: Scale development and preliminary empirical testing. Int J Stress Manage 2001;8:93-111.

34. Dudek B, Hauk M, Merecz D. Assessment workaholism as a behavioral tendency: The polish adaptation of the Mudrack and Naughton questionnaire. Med Pr 2011;62(2):1-6 [in Polish].

35. Juczyński Z, Ogińska-Bulik N. Measurement tools of stress and coping. Warszawa: Pracownia Testów Psychologicznych; 2009 [in Polish].

36. Dudek B, Hauk M. Brief scale of vocational stress (BSVS). Med Pr 2010;61(4):479-87 [in Polish].

37. Cichocka A, Bilewicz M. What lies in non-significant statistical effects? Applications of suppression analysis in social psychology. Psychol Społ 2010;5(14):191-8 [in Polish].

38. Preacher KJ, Hayes AF. Asymptotic and resampling strategies for assessing and comparing indirect effects in multiple mediator models. Behav Res Methods 2008;40:879-91.

39. Michel JS, Kotrba LM, Mitchelson JK, Clarc MA, Baltes BB. Antecedents of work-family conflict: A meta-analytic review [cited 2011 Feb 21]. J Organ Behav 2011;32(5):689-725. Available from URL: http://onlinelibrary.wiley.com/ doi/10.1002/job.695/full011.

This work is available in Open Access model and licensed under a Creative Commons Attribution-NonCommercial 3.0 Poland License - http://creativecommons.org/ licenses/by-nc/3.0/pl/deed.en. 